\title{
Research on Teaching Mode of Automation Major of Application-oriented Undergraduate Universities
}

\author{
Ying-hui LIU, Xiao-dan ZHANG * and Yu-xiang HAO \\ Beihua University, Jilin, China \\ ${ }^{*}$ Corresponding author
}

\begin{abstract}
With the economic development and strong comprehensive national power of China the science and technology strength are continuously improved. In order to meet the need of social development the research on teaching mode of automation major of application-oriented undergraduate universities is a key problem in colleges and universities. Through the aspects of class teaching, education resources and practice the education status of automation major is analyzed. And the theory is proposed that establishment of application-oriented practice teaching system, innovation reform of theory curriculum, optimization of the evaluation system and construction of two dimensions of school-enterprise with combined creative cultivation in depth is an effective way to build up the teaching mode of automation major of application-oriented undergraduate universities.
\end{abstract}

Keywords: Application-oriented; Automation major; Teaching; Mode

\section{Introduction}

With the continuous improvement of science and technology in our country, the machinery manufacturing industry has developed with constant innovation. The students graduated from automation major in colleges and universities have got more offers with the demands of different enterprises in the employment market. In the future with the continuous development of application of automation technology, the students of automation major will receive much concern in economic life and many other areas. At the same time many well-known foreign enterprises with large-scale continue to enter the Chinese market. Domestic enterprises also continue to face the world. The degree and level of demand of professional and technical talents are improved continuously. How to provide applicable talents for the enterprises and how to cultivate high quality and innovative technical talents to adapt to the times is an important problem for the curriculum reform and development of automation major in colleges and universities.

\section{Analysis on The Teaching Situation Of Automation Major}

The specialty goals and curriculum provision of application-oriented automation major in undergraduate universities are under the guidance of education in our country. The main goal is to cultivate advanced applicable technology talents for our country who will be engaged in the design, research, manufacturing, management and operation of production line in related fields.

The Aspect of Class Teaching.In the teaching process of automation major of undergraduates the professional teachers mainly use the teaching mode of cultivating research-oriented talents. During the teaching courses theory teaching gradually transfers to practice teaching. It is realized the theory and practice of knowledge are equally important. The specialized curriculum is an important theoretical basis for the students of automation major when they need to practice on the front line of work. It is an important guarantee for cultivating innovative talents majoring in automation. It is an effective way to analyze and solve professional problems by the means of professional theory learning in proper sequence combined with more targeted training and practice and improving practical ability of profession and technology. At the same time it is the inevitable process to develop automation major students. At present, the cultivation of innovative talents in China is still in the 
developing stage. The construction of professional curriculum system has not yet fully mature. All kinds of targeted teaching reform continue to explore and make improvements. Theory teaching and practice teaching are not completely integrated into effective. Complete implementation of cultivation of innovative talents is constantly improving.

The Aspect of Education Resources.With the development of large-scale and maturity of higher education in our country, the enrollment scale of universities has been expanding. On one hand, it is in accordance with the corresponding ratio of teachers and students to make the enrollment plan in the universities. But the number of professional teachers is not enough and heavy teaching tasks are relatively tight. All these problems have brought greater pressure for teaching and practice of courses. At the same time, the professional teachers have to face important scientific research tasks in the course of teaching. So the professional teachers are confronted with not enough energy for teaching courses. In addition, cultivation of innovative talents need advanced innovative team of professional teachers. It is the actual situation of professional teachers that they are lack of practical experience and innovative thinking and have the problem of theory separated from practice. Recently with more attention and more training the quality of professional teachers are improved to a large extent. But still the advanced study and innovation training of professional teachers need to be strengthened. On the other hand, in terms of practice of students teaching aids and equipments can not be updated timely which makes the practice courses of students are derailed completely from the technology work of actual job. It cannot satisfy the demand of actual technology jobs.

The Aspect of Practice. At present, during the course of practical teaching of automation there are still some problems of insufficient innovation practice in some universities. Part of the experimental teaching stays on the aspect of verification of experimental principles and technical level of experimental operation. During the practice course there is lack of attention on cultivation of innovative thinking, such as self-design of experiments and improvement and innovation of experiment methods. Meanwhile, in the aspect of graduation design when the students of automation major select the topics too much emphasis is placed on the theoretical analysis but is seldom mentioned about the actual application. In the aspect of practice, the mode of visit practice and publicity and explanation from enterprises are taken by some colleges and universities. No effective training is available from the application of practical technology. It reduces the effect of the traditional production practice seriously. In addition, in engineering colleges and universities the cooperation of school and enterprises is the main base for practice and employment of students. But in the actual process of cooperation it is lack of clear goals of cultivation. So the cooperation of school and enterprises can not effectively achieve the desired effect. The cultivation of innovative talents has become a theoretical thing. The creative thinking of the students could not be effectively exercised and expressed. The cooperation of universities and enterprises has become formal and has lost the real meaning of advocated cooperation.

\section{The Effective Way to Construction of The Teaching Mode of Automation Major in Application-Oriented Undergraduate Universities}

With the continuous progress of science and technology the advanced application-oriented technology talents has become the leading force of enterprise transformation and upgrading and advanced technology innovation. At present the construction of the teaching mode of automation major in application-oriented undergraduate universities is a vital task to cultivate the professional talents needed for the society.

The Establishment of Application-oriented Practice Teaching System. The automation major in colleges and universities is a major which focuses on practice teaching and theory teaching. Therefore, in the process of professional development and curriculum setting the construction of practice teaching system should be emphasized. It can be seen from the requirements of the cultivation objectives of automation major that the overall cultivation standard is to have a solid theoretical foundation and to have the technical ability to analyze and solve the problems of automation in the industry. It is to improve the practical ability of students by strengthening the 
practice of courses of sequence control, motion control and automatic instrumentation and equipments. At the same time, the establishment of the open project is to make the self design combined with theoretical study and practice. It is to exert independent innovation thinking of students and to improve the research ability of students of exploration and acquisition of knowledge. And professional cultivation of application-oriented talents of undergraduate colleges will be implemented finally.

The Innovation Reform of Theory Curriculum and Optimization of The Evaluation System. The orientation of the cultivation of application-oriented innovative talents should be based on practical application and aiming at cultivation of professional talents needed for society. Therefore, in the process of focusing on the cultivation of practical creation thinking a solid foundation of professional theory should be laid. It is particularly necessary to form a theoretical curriculum which is suitable for cultivation of innovative talents. On one hand, on the aspect of curriculum reform the basic courses and professional courses would be combined effectively. It is fully implemented by the development of cultivating innovative talents. The mutual relations among different courses would be strengthened. At the same time practical operation skills should be highlighted and the theory of learning should be firmed. It is an effective way to improve the quality of professional theory and practice simultaneously and to cultivate the compound-type innovative talents of application of automation major. On the other hand, on the aspect of evaluation system optimization and upgrade of the system are made to set up the evaluation system which is based on the combination of theory and practice targeting on cultivation of application-oriented talents. The excessive dependence of traditional theory written examination would be changed. Through the method of group discussion, professional fault detection and application of technology operation on analysis the integrated development of students would be fulfilled by comprehensive evaluation based on grasp of knowledge and development degree of ability.

The Construction of Two Dimensions of School-enterprise With Combined Creative Cultivation In Depth. In the future the economic situation of China will be in a rising trend. The need of professional and technical talents from employment market will continue to rise. The development and innovation of enterprises cannot be separated from the cultivation of professional talents in colleges and universities. Because of the professional characteristics of automation major deep cooperation between universities and enterprises will help enterprises to develop rapidly and get "win-win" achievements for both sides. In the aspect of depth cooperation of school enterprise enterprises can forge professional talents with the cooperated universities according to their own needs. Meanwhile, at the first time the universities can grasp information of market demand of talents and make timely, effective and accurate adjustment on the curriculum and practice of training. In the whole process universities and enterprises have connected seamlessly. It provides accurate information for the cultivation and development of university professional talents. At the same time, during the process of depth cooperation enterprises can provide professional internships for students. This enables students to get the professional practice and application in a real sense. The actual operation ability can be greatly improved and innovative thinking and entrepreneurial consciousness can be preliminary cultivated. Meanwhile, during the process the students themselves can also find many deficiencies. When the practice is finished the students can make self adjustment and improvement with target. This is to achieve their own improvement of comprehensive strength and the triple-win of universities, enterprises and students.

\section{References}

[1] Chen Zhiye. The Research on the Curriculum System of Automation Major in Application-oriented Undergraduate Universities [D]. East China Normal University, 2016

[2] Liu Youyao, Jiang Lin, Du Huimin, Zhang Liguo, Gong Jiamin, Liu Jihong. The Research and Practice on Cultivation Mode of Application-oriented Engineering Innovative Talents [J]. Research in Higher Education of Engineering, 2015, (05): 76-81. 
[3] Peng Xiwei, Liao Xiaozhong, Dong Lei. The Exploration and Practice on Teaching Reform of Curriculum of automation major [J]. China University Teaching, 2016, (01): 72-74.

[4] Su Kezhi. The Research on Cultivation Mode of Innovative Engineering and Technical Talents of Research-oriented University [D].Dalian University of Technology, 2013.

[5] Yang Guoshi, Jia Qun. The Construction of Teaching resources database for automation major courses [J]. Journal of Huainan Teachers College, 2010, (03): 85-86. 